\title{
Beneath the Surface: \\ Sleeping Beauties in Representations of Antiquity and their Reception (1860- 1900)
}

\section{Anne-Florence Gillard-Estrada}

British painting in the mid 1860s saw a prominent renewal of paintings of Antiquity that was to last until the early twentieth century. The painters concerned have sometimes been referred to as 'Olympians', 'Neoclassical' or 'Parnassians' ${ }^{\text {'1 }}$ because of their academicism, their return to classic forms and their promotion of noble ideals. Recent specialists have placed some of these painters - mostly Frederick Leighton and Albert Moore - within the broader Aesthetic Movement. ${ }^{2}$ However, both categories are problematic. First, neither completely accommodates painters such as Lawrence Alma-Tadema or Edward Poynter, who produced a kind of historical genre painting similar to that in vogue in France. ${ }^{3}$ Moreover, the term 'Olympian' connotes a serene and luminous Greece which is more akin to the Hellenism that art historians such as Winckelmann envisioned: this idealized and sanitized concept, therefore, precludes the darker and more complex elements of Greece which these painters in fact took into account in their works. Then, the inscription within the Aesthetic, or 'Art for Art's Sake', Movement posits the primacy of the formal qualities of painting at the expense of subject, and yet these painters were highly concerned with literary, dramatic, historical or mythological subjects, even though they sometimes explored Aesthetic principles. Finally, beyond the formal beauty and the noble ideals these painters wanted to attain, their works express concerns for inner conflicts and hidden pulses which neither term - 'Olympian' or 'Aesthetic' - completely account for.

One of the privileged themes of that painting is the representation of sleeping women. The sleeping figure is sometimes presented by some of these painters as a purely formal motif, in accordance with the principles of Aestheticism; however, it also carries symbolical and erotic connotations because of the pose and the treatment of the body and clothing. The sleeping figure is closed in on her intimacy and interiority and there is no interaction with the spectator. If this beholder is assumed to be male, he may therefore freely project his desire onto her. In that case, the presentation is ambivalent - and so is the participation of the spectator - for the frontier between sleep, eroticism and death is porous.

The representation of sleep also provides an access to the unconscious: the contorted poses and the sleeping bodies express buried dreams and desires. This was in keeping with the context: the contemporary advances in psychology and anthropology here meet the revaluation of Greece then taking place in classic studies and archaeology. The vision of Greece was still divided into the construct of a "white" Greece that had ideological, political, racialist and gendered resonances on the one hand and the newer approaches that reappraised the chthonian, Eleusinian or Dionysian dimensions of Greece on the other hand. The divide was between the notion of an immaculate, idealised Greece - whether in its conception of art or of man - and a darker, more disquieting vision that accepted the savage elements of rites and the role of colour in sculpture. Notably, the painters associated to the revival of Greek forms were highly influenced by these contemporary reappraisals of Greece.

See Christopher Wood, Olympian Dreamers: Victorian Classical Painters, 1860-1914 (London: Constable, 1983), 15-32.

See Elizabeth Prettejohn, Art for Art's Sake: Aestheticism in Victorian Painting (New Haven \& London: Yale University Press, 2007).

Notably the French 'Néo-grec' painters Gérôme, Hamon and Picou. 
The representations of sleeping women either drawn from Greek subjects (such as mythology) or influenced by Greek forms reflect such divide. The female figure is inscribed within a prestigious academic and iconographic tradition that posits the primacy of classic forms, which accounts for her sculptural treatment and her draperies; but her body is also an object of erotic fascination while sleep evokes the realm of the mysterious and the uncontrolled. Her body becomes the site of a collision between Ideal Beauty and the libidinal. Underneath the codified and widely accepted pictorial treatment of the figure, signs of unconscious desires irrupt. This painting, therefore, reflects concerns pertaining to the body, to sexuality and to the hidden recesses of the mind. What is more, such concerns are also present in the critical and journalistic reception of this painting.

The late-Victorian painters of the Antique found inspiration both from Greek statuary and from Renaissance painting, which confers a sensual note to their feminine figures, who are thus poised between an overt idealization and a mild sexualisation. But establishing a clear divide between the classical form and the graphic expression of fantasy is not totally possible and so the body of the sleeping woman is cleft between the idealizing classical discourse and the fleshly reality of the body offered for consumption. The repressed returns from beneath the smooth, sculptural surface, despite the iconographical and discursive 'vesture' that clothes the figure, to take up Didi-Huberman's arguments about the impossibility to completely dissociate form and desire. ${ }^{4}$ The painters indeed wanted to renew with the elevated subjects and noble forms of the Antique, sometimes referring to Ideal Beauty and to noble passions, and such choice is supposed to entail an operation of desexualisation. However, the tone and discourse present in the critical reception of this painting show that what is at stake in such painting is desire and the body. Indeed, the critical discourses pertaining to such works purport a verbalization of the repressed fantasies at work in this 'Olympian' painting.

Many of these painters took up the subject of the sleeping Ariadne, which has often traditionally conflated eroticism and dream. Many Greek vases represent Ariadne when Dionysus discovers her or when she reclines with him; some vases, frescoes or sculptures show her asleep. G. F. Watts made various paintings of semi-nude or draped Ariadne, who is shown seated on the rocks, alone or with attendants. She is awake and often aware of the coming of Dionysus and his retinue. Prowling leopards, animals symbolizing pagan energy and sensuality, announce the irruption of the god. ${ }^{5}$ In 1863 , he devised another version of the subject that shows Ariadne sleeping, ${ }^{6}$ which exudes a blatant eroticism because of the languorous pose of Ariadne and the sensuality of the texture. Other painters chose to represent her as the woman abandoned by Theseus, moaning, lamenting or sending imprecations to the sea, and sometimes acting as an excuse for the representation of the nude. ${ }^{7}$ Yet she is never represented with her divine mate.

In their study of Leighton, Leonée and Richard Ormond state that he was haunted by the symbolism of sleep, especially by its stillness and by the idea of 'death-in-life' as 'a suspended state, which may or may not prefigure movement, or may move towards death'. They also acknowledge the eroticism of his representations, an element that surges up in contemporary reviews of his works. Leighton's version of the subject of Ariadne is highly

‘ See Georges Didi-Huberman, Ouvrir Vénus: Nudité, rêve, cruauté (Paris: Gallimard, 2002).

Watts, who admired the Elgin marbles of the British Museum, modelled his different versions of Ariadne on the three goddesses of the Parthenon.

- G. F. Watts, Ariadne, 1863, oil on canvas, private collection, $36.1 \times 76.8 \mathrm{~cm}$.

See William Blake Richmond's Lament of Ariadne (exh. 1872), Evelyn de Morgan's Ariadne in Naxos (1877), Ariadne in Naxos by Henrietta Rae (1885) and Ariadne by Herbert Draper (1905).

s Leonée and Richard Ormond, Lord Leighton (New Haven: Yale University Press, 1975), 131. 
ambivalent: she seems to be sleeping yet the title ${ }^{9}$ tells a different story. Leighton indeed refers to another version of the myth in which Ariadne dies. His figure is modelled after the 'Vatican Ariadne', ${ }^{10}$ although the original position of the sculpted figure is slightly altered: she lies on the rocks, her body forming a straight diagonal, and her bosom is entirely covered by a drapery. What the artist aims at is the sense of definitive passivity brought about by death and not the pause of sleep before the return to sensual bliss. However, despite the rigidity of death, the female form invites an erotic contemplation.

The theatrical presentation of the figure should be taken into account: the title reads like a stage direction; a flat background evokes a backdrop; and the figure is positioned like an actress placed on the front stage, her body and head enhanced by a dark greenish drapery. Her overdramatic face expresses pathos and she adopts the affected pose of a tragedian. The colours of the painting contribute to the tragic dimension: the skyline above her creates a horizontal line that encloses her and is hardly relieved by the harsh jagged lines of the mountains on the left. The water has a dark violet colour that harmonizes with the sad brown shades of her drapery and the sombre hues of the vegetation. The colour of the sky is dull and matches the dry rocky platform; it contrasts with her very luminous white dress and her pale skin, which seem lit by an artificial light. There is much ambivalence in the treatment of the figure: her very pale skin and rigid pose point to death, but her transparent robe and smooth limbs invite the spectator to the voyeuristic contemplation of a beautiful body. Leighton's version of the myth excludes the possibility for Ariadne to meet Dionysus and to accede to the pleasures of the senses; in its place, Artemis, the goddess of virginity, petrifies her beauty into death. She is frozen, pure and statue-like, which is why Leighton selects white for her drapery, instead of the sensual red colour chosen by Waterhouse, De Morgan or Richmond for their representations of Ariadne.

Some critics were particularly fascinated by this freezing touch. According to William Michael Rossetti, for example, the deadly stasis that follows Ariadne's intense longing for Theseus is salutary: 'this woman has died of the very weariness of daily renewed grief. But the calm now is as profound as the yearning heretofore', which is why he notes 'a sensation of stationariness, as if Phoebus Apollo might be pausing in heaven to see how his sister Artemis has accomplished her mercy upon the outworn Ariadne'. ${ }^{11}$ Desire for Theseus is met by death, but this is envisioned in terms of a relief. The same rhetoric is present in the anonymous review for the Art Journal: 'life tranquilly ebbs away from the figure; the drooping wrist and pendent finger are as the fading and falling of a flower when life is spent. Rest, eternal repose, after earth's turmoil, is the spirit the artist has cast over the scene. [...] Artemis at length releases Ariadne from her misery'. ${ }^{12}$ The critic expresses a curious kind of death wish as relief from pain is only brought about by death; yet this does not prevent the critic from appreciating the body parts of the beautiful figure.

F. G. Stephens, writing anonymously for the Athenaeum, uses a striking simile to refer to her death: 'Ariadne lying in royal beauty, just as life passed from her, rather than death came to conquer so sweet a form'. ${ }^{13}$ The traditional conqueror, Dionysus, has indeed been excluded. Besides, her morbidity is seen as a source of beauty. 'Royal as she was in regal ease of dying, with ordered feet placed together, and limbs as though they rested. [...] Fair she is, with a

- Frederic Leighton, Ariadne abandoned by Theseus; watches for his return. Artemis releases her by Death, 1868, oil on canvas, Salar Jung Museum, Hyderabad, India, 101 x $157 \mathrm{~cm}$.

${ }^{10}$ Sleeping Ariadne, 100 A. D., Roman copy of the Hellenistic marble sculpture of the second century B. C., Vatican Museums.

"William Michael Rossetti, Notes on the Royal Academy exhibition, 1868 (John Camden Hotten, 1868), 12.

12 [Anon.], 'The Royal Academy', The Art journal vol. 7 (June 1, 1868), 101-10: 105.

'3 [G. F.Stephens], 'Royal Academy', The Athenaeum 2114 (May 2, 1868), 631-33: 632. 
noble face and lips that are paler than their wont since their corners sank; the eyelids sheathed imperial eyes and all the haughty lines of loveliness relaxed on cheek and throat and bosom'. ${ }^{14}$ Like many of her contemporary sleeping sisters conquered by death and not by a man, her very rigidity originates a highly ambivalent erotic contemplation. Unlike many of his other sleeping figures, such as Cymon and Iphigenia or the figure of Flaming June, Leighton's Ariadne is an object of desire that is safely located in death. And while many representations of sleeping beauties posit the presence of a beholder either situated in the pictorial space - the man who contemplates her and who will wake her up and therefore awaken her senses -, or displaced onto symbolical elements - Dionysus/Bacchus represented by his animals or Zeus assuming an elemental shape -, the erotic potential of the sleeping woman is also addressed to the spectator of the painting, most often presumed to be male.

J. W. Waterhouse devised his Ariadne ${ }^{15}$ as a tribute to Leighton's painting ${ }^{16}$, but he chose life and Eros instead of Thanatos. He too was inspired by the Vatican sculpture but unlike Leighton, Waterhouse kept the languorous positions of the arms and head as well as the drapery uncovering her right breast. ${ }^{17} \mathrm{He}$ used colour symbolism to accentuate her robe which accentuates the sensuality of the sleeping figure; the deep red provides a warm note that matches the voluptuous treatment of the textures. As in Leighton's Flaming June, her desirable body radiates and is enhanced by the clinging drapery. The symbolical bright light of dawn illumines the mountains and announces the return of bliss. Waterhouse takes up the same spatial disposition as in his Saint Cecilia (1895): the figure is no longer placed on the shore or on a rocky promontory but in a terrace which occupies the foreground; the background shows the port and Theseus' sailing ship. The perspective is derived from Italian paintings of the Quattrocento. This explains why F. G. Stephens saw a difference of treatment between Leighton's classicism and Waterhouse's return to the Renaissance: 'The dead "Ariadne" of Leighton furnishes a curious example of the purely classical way of regarding the subject. Leighton's conception of the theme is that of a Greek of a Roman epoch; the present picture is the offspring of Florence, but has a dash of Lombard directness'. ${ }^{18}$ To Stephens, this 'directness' probably implies a more straightforward sensuality. Many elements express reverie and erotic longing rather than sleep. Ariadne's body and feet are tense. Desire and animalism are displaced onto the leopards, animals associated to Bacchus and his maenads; one of them is sleeping, quietly curled around her footstool, while the other one is approaching both the other sleeping panther and the woman; the cat, therefore, signals Dionysus's imminent irruption and his power to arouse desire. As in much Symbolist art, such paintings of the Antique, therefore, draw on mythology to express sexual fantasy.

Although Leighton sometimes experienced with paintings that aimed at beauty for its own sake and so showed his interest for Aesthetic principles, he was nevertheless eager to represent recognizable subjects and themes. He regularly mentioned in his writings and letters

\footnotetext{
${ }_{14}$ Ibid.

John William Waterhouse, Ariadne, 1898, oil on canvas, private collection, $91 \times 151 \mathrm{~cm}$. See http://upload.wikimedia.org/wikipedia/commons/9/97/John_William_Waterhouse_Ariadne.jpg (all images accessed Aug. 2013).

${ }_{16}$ Waterhouse admired and emulated Leighton and saw the retrospective held after his death in 1897; see Peter Trippi, J. W. Waterhouse (London: Phaidon, 2002), 152-7.

"Ariadne adopts the position seen in many antique representations of sleeping figures of Ariadne or maenads in vases and sculptures - with one arm placed over the reclining woman's head and often resting on the other arm.

1s [F. G. Stephens], 'The Royal Academy (First Notice)', Athenaeum 3679 (April 30, 1898), 571-4: 572.
} 
that 'classic forms' are timeless, 'abstract' and therefore perfect. 'Summer Moon' $(1872)^{19}$ has therefore been classified among his 'Aesthetic' works, in which only the formal qualities count. When it was exhibited, the journalist of the Academy described it as 'a pictorial poem' in which 'two young women have fallen asleep curled against each other' and in which '[e]very sweeping line of drapery, every shade of colour, combine in one lovely harmony'. ${ }^{20}$ However, this decorative treatment of the figures was rejected by many critics, among others Henry Morley: 'I can see only the loveliest of wall ornaments [...] I find in them deliciousness of form and colour, nothing more. "Summer Moon" is a sort of flower painting with forms of fair women for the flowers'. ${ }^{21}$ Still, Morley uncovers the gendered ambivalence that is at stake in the purely formal and decorative treatment of the female figure: such aesthetics turns the sleeping women into objects offered for the beholder's contemplation into flowers, so to say, and Morley's image is certainly highly connoted.

Many critics ambivalently concentrated on the formal qualities of the work while dwelling on the eroticism of the women, which is enhanced by their passiveness. Sidney Colvin, for one, refers to the work as the 'choicest and most poetical piece of pure decorative work, in the classical spirit', and then evokes the physical beauty of 'that lovely and solemn group of two women who lie coiled side by side draped in wine-colour, and steeped in sleep, with poppied weight and warmth in the rhythmical repose of their large and tender limbs'.22 He evokes the topos of the stupor induced by drug (the poppy connotes laudanum) or by alcohol (with the term 'wine-colour'). Besides, his description of the 'coiled' women is a near-verbalisation of the Sapphic fantasy that may be suggested by the representation. The treatment of the two interlocked female bodies allows participation from a presumably male beholder. Indeed, despite the recurrent allusions to the painter's interest in formal beauty and to his quest for musical harmony, many critics were particularly inspired by the poses and the sleeping attitudes of the models, which are evocative of mystery and eroticism.

Stephens, for example, insists on the purely 'aesthetic' dimension of the work:

\begin{abstract}
Not so much is aimed at in Moonlight; but there is not less Art displayed [...]; the poetic inspiration is beyond question; the whole work is in perfect harmony with itself - a great quality in Art, and how little understood! Here are colours of the greatest and most delicate intensity, breadth, broad tone, chiaroscuro of the subtlest, such a noble grouping of the figures, such grand suavity of line, and a composition so melodious, if one may employ a term which is unfairly monopolized by music, that the company of such a masterpiece is exalting, delightful, purifying. ${ }^{23}$
\end{abstract}

There seems to be an effort on the part of the critic to justify the nobility of that representation: words like 'noble' and the allusion to the 'purifying' effect on the beholder concur to legitimize a subject that is not validated by any reference to myth or history; still, the painting opens up a whole realm of fantasy, precisely because it only depicts sleeping women curling up against each other. The inscription of that painting within the academic tradition is not self-evident, and so using the discourse of Aestheticism was an alternative way to justify a subject that contains a highly erotic dimension.

Leighton's sleeping women are often akin to the mysterious and voluptuous female sleepers of Symbolist art. In Summer Slumber (ca. 1894) ${ }^{24}$ a woman is sleeping on a bench that is

${ }^{19}$ Frederic Leighton, Summer Moon, ca. 1872, oil on canvas, private collection, 100.3 x $128.3 \mathrm{~cm}$. See http://www.gutenberg.org/files/35935/35935-h/35935-h.htm\#imagep193a.

${ }_{20}^{20}$ [F. G. Stephens], 'Note on the fine arts: Leighton's Summer Moon', Academy vol. 3 (April 15, 1872), 148.

"Henry Morley, 'Pictures at the Royal Academy', Fortnightly Review 11 (1872), 692-704: 701.

"2 Sidney Colvin, 'Pictures in London and Paris, 1872', Cornhill Magazine 26 (July 1872), 33-47: 41.

${ }_{23}^{2}$ [F. G. Stephens], 'The Royal Academy I.', Athenaeum 2323 (May 4, 1872), 563-6: 564.

${ }_{24}$ Private collection. See http://www.gutenberg.org/files/35935/35935-h/35935-h.htm\#imagep316a. 
flanked by two bas-reliefs of sleeping figures. One enigmatic standing statue bids the witnessing spectator to hush up, while another statue represents a sleeping woman, so that there is a mise en abyme of the theme of sleep. The sculptures of sleeping figures are modelled after Michelangelo's Vatican frescoes, such as the massive Sibyls, who wear hoods and are constricted within a square space, and they contrast with the sleeping woman, who lies horizontally and whose hair is let loose. A whole realm of dreams and fantasies is suggested: the undulating folds of her vesture emphasize the voluptuous lines of her body; her gown and the drapery on which she rests seem literally to flow out of her body - as if some fluid energy was escaping from her body while she is sleeping. This is a recurrent motif in Leighton's painting.

Stephens dwells on the sensual depiction of the sleeping beauty who is envisioned as a 'virginal' woman offered to male scrutiny:

Several weeks ago, we very briefly described 'Summer Slumber', a Greek room lined with marble, adorned with statues of 'Silence' and 'Repose,' and other sculptures of subjects suggestive of peace and slumber. [...] This landscape is as restful in its sentiment as the nearly life-size figure of a young damsel extended supine upon the margin of a marble tank filled with water, which reflects the darker azure of the sky without, while its colour has been ably harmonized with the pale auburn of her hair and the deep tender rose of her draperies. These draperies [...] veil, without concealing, the fine lines of her body and her virginal contours. Her limbs and face are charmingly drawn, and modelled with delicate research. ${ }^{25}$

The critic places himself in the position of the spectator contemplating a sensually passive virgin; he seems particularly titillated by the woman who sleeps innocently. His discourse oscillates between his general impression that the picture is 'warm' and elements that tone down its emotional charge, such as the 'pale auburn' of her hair and the 'tender rose' of her draperies. However, the critic's evocation of the voluptuous shapes of the sleeper contrasts with the soothing effect that such a representation of repose is supposed to procure. This prose thus functions like Winckelmann's ambivalent rhetoric of the purifying effect of idealized Greek forms, which is constantly annihilated by the erotic responsiveness to the fragmented parts of the sculpted body.

Leighton took up the figure of the right-hand bas-relief to devise the composition of Flaming June. ${ }^{26}$ The body occupies the whole space of the canvas and is again inspired by Greek sculpture and by Michelangelo's frescoes. The title and the vivid dress of the sleeping figure evoke the themes of heat and passion. The chromatic arrangement is based on warm colours: the bright orange colour of her gown; the red hues of the drapery and flowers; the auburn colour of her hair. The transparent gown reveals the contours of the body, mostly her bosom and thighs. Prettejohn sees this painting as another example of Leighton's exploration of the principles of Art for Art's sake: there is no reference to a clear modern social context and the body carries 'its meaning within itself'. ${ }^{27}$

However, besides this notable 'Aestheticist' dimension, the painting also belongs to Symbolism. The theme of sleep evokes the buried realm of dreams and of the unconscious, which enhances the erotic presentment of the woman's body. Despite the theme of rest, the compressed body, crossed by the diagonal thigh, is full of tension. Her vesture, moreover, literally flames outward towards the spectator. She is not the usual virginal girl clad in white who sleeps in utter abandonment.

${ }_{25}^{2}$ [F. G. Stephens], 'The Royal Academy (First Notice)', Athenaeum 3471 (May 5, 1894), 583-9: 583.

${ }^{26}$ Frederic Leighton, Flaming June, ca. 1895, oil on canvas, Museo de Arte de Ponce, Puerto Rico, 119 $\mathrm{x} 119 \mathrm{~cm}$.

${ }^{27}$ Prettejohn, Art for Art's Sake, 146. 
Leighton's anecdote about the composition, which frequently recurs in reviews or monographs of his work, seems hardly believable: he mentions that he was charmed by the pose of a model who was having a rest, which he transposed into a quick drawing. Yet the composition seems clearly inspired by Michelangelo's destroyed painting Leda, of which only drawings or sketches are left, as well as engraved or painted copies by other artists. ${ }^{28}$ In these, the prominent thigh occupies the first plane of the canvas; in Leighton's painting, it becomes creates a horizontal line that divides the composition. Interestingly, the theme of Leda and the swan has traditionally been treated as an erotic painting: in Michelangelo's version, Leda is lying and is literally copulating with the swan, his beak placed against her mouth and his wing on her crotch. Her eyes look downwards but she is not sleeping. One oil copy in the National Gallery, which Leighton may have seen, shows a crimson drapery beneath her whose shape and folds evoke female genitals. Leighton removed the erotic theme and the phallic swan and slightly altered the position of the body and arms, only keeping the Michelangelesque contorted figure and the large thigh. But he was unmistakeably inspired by an overtly erotic painting.

In fact, Leighton displaces the erotic overtones onto other elements. The sea that can be glimpsed above her reflects the sun. Although the figure seems to be sleeping, the rippling drapery beneath her expresses the inner world of dreams and desire: it glows with a bright orange colour that connotes passion; again, this drapery looks like a kind of liquid flow of bodily energies oozing out of her body. Despite her languor, probably induced by the heat of June, the posture of her body and the placing her feet all point to muscular tension: one foot evokes the dancing foot of maenads, or of the Gradiva, ${ }^{29}$ while the rectilinear folds of the drapery enhance the projection of the other foot.

Notwithstanding its smooth academic texture, Leighton's painting deals with desire. The sleeping figure seems inaccessible and shut in her inner world of dreams and fantasies; but her body is contorted by erotic anticipation. This element was to be later uncovered by Klimt, whose Dana $\ddot{e}^{30}$ is clearly inspired by Leighton's composition and chromatic choices: both paintings use warm colours, orange and crimson, which denote passion; the golden rain is a variation on Leighton's representation of the golden light of the sun showering down on the woman. But Klimt further unveils the erotic dimension of Leighton's picture by transposing this sleeping woman into Danaë, whose myth was close to Leda's in that both were inseminated by Zeus, either in the shape of a swan or of rain. In between, Leighton had already transposed Michelangelo's representation: Leda, impregnated by the swan, is remodelled as a sleeping woman who languorously receives the sensual rays of the sun god.

This erotic element titillated some of its commentators. Stephens, in the Athenaeum, perceives signs of passion in the figure, despite the theme of sleep: 'Her face is flushed in sleep, and the broad and heavy eyelids lie close upon her cheek, while the full lips part'. ${ }^{31}$ The term 'flushed' evokes signs of inner agitation, and the critic then alludes to the 'intense red' of the drapery underneath her, described as 'the highest key-note of the chromatic scheme' and emphasizing the undercurrent theme. 'The idea which is embodied in the sumptuous figure of the sleeper is sustained by the fervid coloration of the dress and by the general tenor of the landscape'. ${ }^{32}$ Thus, the idea which he refers to here is not so much that of repose as that of emotion and fever.

\footnotetext{
${ }^{28}$ Michelangelo's Leda follows the same composition as Night, one of the marble statues on the tomb of Giuliano de Medici in San Lorenzo Church (Florence). There were copies by the Rosso Fiorentino and Rubens as well as by later sculptors, such as Bartolomeo Ammanati.

${ }^{2}$ Gradiva, Greek bas-relief, fourth century BC, Roman copy, Chiaramonti museum of Vatican.

${ }^{2}$ Klimt, Danaë, 1907, oil on canvas, Galerie Würthle, Vienna, 77 x $83 \mathrm{~cm}$.

"[F. G. Stephens], 'The Royal Academy (First Notice)', Athenaeum 3523 (May 4, 1895), 574-9: 576.

"Ibid.
} 
Claude Phillips, in the Academy, dwells on the figure lit up by the shine of the sun on the sea, which to him reveals the presence of the sun god. He emphasises the voluptuousness of the woman, which is made acceptable by the classic theme:

[A] most laboriously worked-out study of a damsel in semi-transparent draperies of flame-colour, which cling to her statuesque form in the fashion made familiar by Greek sculpture. She takes her mid-day siesta in the most uncomfortable and complicated attitude that could well be devised, just sheltered by an awning from the arrows of the sun-god, whose full blaze falls upon the sea glowing like molten brass. $^{33}$

Yet such protection from the sun does not seem to protect her from the intrusion of the god, who has caused her draperies to literally melt. This interpretation, which highlights the god's effect on the damsel, must have impressed Phillips for he took it up in another article:

That inconstant divinity, the sun, in his impersonal form, is also the hero of his 'Flaming June,' if the statuesque damsel in her semi-transparent vesture of flame colour is its heroine. The sunlight on southern seas is here unfortunately more like molten brass than impalpable gold. ${ }^{34}$

Like Danaë, who welcomes Zeus in the form of the gold shower, the sleeping figure seems to be tranquilly yet intensely waiting for the showering of the god's blessings on her. There is therefore something beyond the purely formal representation of that sleeping woman: despite the 'Aesthetic' discourse that posits the idea that the body is a motif among others, such dissociation is in fact impossible.

Albert Moore was also particularly inspired by the theme of sleeping women clad in Greco-Roman draperies. His decorative and sculptural figures are often lost in their reveries, to which the beholders do not have access. Yet, despite the painter's avowed adherence to Aestheticism, such representations are sites of conflicting desires too. The figure's almost erotic abandonment collides with the sense of stillness. These figures modelled on the serene statues of classical Greece, with static bodies and inexpressive faces, are nevertheless invested by desire. Their bodies are clad in draperies that enhance the many undulating and rectilinear lines of the painting. This was meant to underline the geometrical and optical effects he aimed at, which was mostly founded on precise chromatic arrangements; and yet the draperies and bodies also express inner tension and expectancy. The figures seem quiet and yet they are also animated by strange reveries and dreams. The idealized classical clothing of the figures does not totally cover the desirable bodies; nor does it conceal the mysterious workings of the psyche. Inertia is aimed at, and yet movement irrupts. The silence of sculpture contrasts with the language of the body.

Comyns Carr mentions the main 'principles' that are at the basis of Moore's works:

[...] that art in its highest flight can take no account of the passions or fortunes of human life, but that it must devote itself exclusively to the rendering of physical beauty, and of those unconscious movements of the body which are made without thought or reflection, and are not associated with any particular emotion. As the eye penetrates deeper into the waters of a lake when the surface is calm and smooth, so Mr. Moore believes that the artist can discover more of the beauty of humanity when it is undisturbed by passion or suffering. He therefore strives to preserve in the faces that he paints an expression constantly happy and tranquil, and he chooses for the interpretation of form only those gestures that are abstract and unconscious. ${ }^{35}$

${ }^{3}$ Claude Phillips, 'The Royal Academy II', Academy vol. 47 (May 25, 1895), 449-50: 449.

${ }^{3}$ Phillips, Claude, 'Pictures of the year (No. I): the Royal Academy and the New Gallery', Fortnightly Review 63, ns 57 (June 1895), 925-39: 932-33.

${ }^{3}$ Carr, J. Comyns, Examples of Contemporary Art: Etchings from Representative Works by Living English and Foreign Artists (London: Chatto and Windus, 1878), 16. 
Carr points to a paradox in the painter's representations of bodies. His art is supposed to deal with exterior form only yet those 'unconscious movements' he refers to contradict that idea and seem to indicate that something is working beneath the surface. Indeed, something thoughts, emotions, drives or pulses - seems to be lurking beneath the quiet waters. Carr's simile of the water is interesting when placed in the context of Symbolist art, in which water is often associated with woman: it indeed often connotes the mystery of womanhood and it symbolizes the hidden recesses of the mind.

The bodies of Moore's sleepers betray many 'unconscious movements', to take up Carr's expression, and these may be interpreted as marks of tension and desire. In A Palm Fan (1875), ${ }^{36}$ the single sleeping figure seems to be reclining languorously and serenely. But one soon notices a number of 'movements': the woman's right arm clutches the back of the sofa; the fingers of her left arm are far from limp; her legs are held close together; her feet are squeezing the blue cloth beneath her. The many straight creases of the draperies provide tension and create a counterpoint to the sinuous lines of the figure. The woman averts her face; her transparent gown enhances her voluptuous bosom and hip. White and yellowish glazes accentuate the soft texture and graceful line of her vesture. Moore's technique was to adjust a body within a geometrical grid, and so the angles and lines of her arms and legs form a criss-cross pattern that parallel the numerous straight lines of the painting. Yet, far from being immobile and rectilinear, her whole body is animated by flowing movements that contrast with the vertical, horizontal or diagonal lines of the couch and draperies.

In his review of the picture, W. M. Rossetti insists on its 'Aesthetic' qualities; but he also lingers on her desirable body. The girl he contemplates is 'distended on a sofa, with very visible contours through gauzy drapery, and pale-blue as the predominant colour' ${ }^{37}$ However, desire for the represented subject becomes yearning for the art object. 'This is a covetable little piece of art' ${ }^{38}$ Rossetti was not the only one who saw such body as a more or less eroticised figure, despite the inertness of sleep. Indeed, the woman's pose imparts a strong seductive character to her. Moreover, although the attention is transferred onto the objects and props that surround the sleeping figure, thus further blurring the investment with her, objects such as fan, jewels or fruit are feminine attributes. Moore often chose to focus on objects that could divest his paintings of any connotations, yet such motifs reinforced their connotative potential. Furthermore, the figure's self-absorption makes her both an object of desire as well as a desiring subject.

A similar composition recurs in Acacias. $^{39}$ The painting is divided into several horizontal compartments on which her draped body seems to have been pasted. The female model adopts a highly uncomfortable sitting position on a couch, and her head is uneasily placed within a square cup formed by her arms. Her zigzagging body is even more geometrical than in the preceding canvas and so the position of the body and the placing of the limbs point to the impossibility of sleep. And despite his purist aesthetic aims, 'unconscious movements' are again at work beneath the still, inexpressive surface of the sculptural figure.

Frederick Wedmore, in the Academy, expresses a deep ambivalence towards the painted figure. He rapturously notes some signs of emotion on her face while pointing to the beneficial effects of sleep: "Acacias" shows us one of the girls who [...], soft, flushed, and

\footnotetext{
${ }^{36}$ Albert Moore, A Palm Fan, 1875, oil on canvas, private collection, 16.5 x $26.6 \mathrm{~cm}$.

${ }^{37}$ Rossetti, W. M., 'The Royal Academy Exhibition (Second Notice)', Academy vol. 7 (May 15, 1875), 513-4: 514.

${ }^{38}$ Ibid.

3. Albert Moore, Acacias, exh. 1882, oil on canvas, Carnegie Museum of Art, 58.4 x $31.1 \mathrm{~cm}$.
} 
warm, are overcome so happily with the gracious sleep of childhood' ${ }^{40}$ Passion is evacuated, and sleep seems to have the beneficial effect of quieting down all emotions and relocating the woman into the safe space of childish innocence. Espousing the principles of Aestheticism which emphasized the harmony of the composition and the beauty of lines and colour - seems to legitimize more or less erotic representations, exactly as the recourse to the idealizing discourse of classicism justified painters in their choice of the nude: 'Mr. Moore's art is an art of refined luxury. [...] But there is rest and satisfaction in it. His world has the repose of lovely line, and the delight of faultless colour'. ${ }^{41}$ But the objectification of the female figure and her pacification through sleep do not totally preclude its potentially erotic charge. Through his motifs and compositions indeed, Moore sets off a chain of thoughts in a way that resembles much Symbolist art: a butterfly or a flower may evoke the themes of the soul, of life or of a renaissance. ${ }^{42}$ Moore's motifs were inspired by Greek or Japanese art, but beyond his formal choices and his Aesthetic principles, his representations of sleeping women are have a distant kinship to the contemporary Symbolist female archetypes.

A number of these representations of sleeping women, then, suggest the presence of a male beholder of the figure. Lawrence Alma-Tadema, in his painting The Women of Amphissa (1887), ${ }^{43}$ went as far as to hint at the potential danger man represents. The painting illustrates a story from Plutarch's Scripta Moralia ${ }^{44}$ in which a group of votaries of Dionysus from Phocis, the Thyades or Maenads, inadvertently stray into the neighbouring hostile city of Amphissa. Exhausted by their frantic nocturnal Bacchanal, they finally sleep on the marketplace and are discovered by the women of Amphissa in the morning. These, fearing that the soldiers and men of the city should assault the defenceless women, wake them up and accompany them safely out of the city. The artist already tackled the theme of maenads sleeping off a Bacchanalian revel in his Exhausted Maenides after the Dance of 1873-4 and After the Dance (1875), two instances of Alma-Tadema's erotic depiction of sleeping nudes. Here, he establishes a contrast between the heavily draped matrons of Amphissa and the maenads lying centre stage. The matrons' neat draperies and hair differ from the maenads' dishevelled manes and neglected clothes. Moreover, the animal skins they wear relate them not to humanity but to animalism, while woven clothes refer to human technè.

Many commentators of the picture use words pointing alternately to frenzy or to abandon. But when placed next Gleyre's or Bouguereau's bacchantes, Alma-Tadema's were far less erotic or unruly. Claude Phillips was among the critics who were aware of that. Although he admires them, the maenads look too orderly and pure, and therefore hardly plausible:

In the present instance it is impossible not to admire the consummate skill with which is disposed the artfully-artless group or chain of these so-called Maenads, of whom some appear prone, some halfstanding, some half-lying, in the most cunningly varied attitudes, having yet a certain unity as a whole. Very beautiful are many of the golden-haired priestesses, too fresh and cool in their unsmirched purity to suggest exhausted devotees of Dionysos, left powerless now that the frenzy, against which to strive is vain, has died away. ${ }^{45}$

\footnotetext{
«o Wedmore, Frederick, 'The Grosvenor Gallery', Academy vol. 21 (May 6, 1882), 326-7: 326.

"Ibid.

"The Greek word for butterfly was psyche, which also means 'soul', and so the insect here evokes the fleeting soul. In many ancient Mediterranean traditions, the acacia of the painting's title evokes resurrection, eternity or immortality and is present in funerary symbolism.

${ }^{43}$ Lawrence Alma-Tadema, The Women of Amphissa, 1887, oil on canvas 129 x 182.9, Sterling and Francine Clark Art Institute, Williamstown, USA.

* See J. R. Barrow, Lawrence Alma-Tadema (London: Phaidon, 2001), 130-4, and V. G. Swanson, The biography and catalogue raisonné of the paintings of Sir Lawrence Alma-Tadema (London: Scolar press, 1990), 69 and 173.

${ }^{45}$ Claude Phillips, 'The Royal Academy', Academy vol. 31 (May 7, 1887), 330-2: 331.
} 
Despite their animal skins, their immaculate white gowns jar with their traditional image, and this is why Phillips estimates that the artist has failed to depict 'the dramatic contrast between the Maenads, no longer possessed with a Bacchic fury, but bearing still its traces, and the unmoved calm, tempered with sweet pity, of the women of Amphissa'. ${ }^{46}$ The Maenads are too innocent and pure and the 'clash of human passion' ${ }^{47}$ that is expected from such subject is consequently missing. Some spectators, then, seem to have found such a representation too tame to their tastes.

Other critics were quite receptive to the voluptuousness of the reclining figures, as is the case with Stephens, who, in the Athenaeum, lingers on the women's abandoned bodies:

We particularly admire the girl who lies, fast asleep, on a skin in the foreground, her finely drawn limbs, her handsome face still flushed with the excitement of yesterday, and the excellent colouring and modelling of her flesh, especially of her legs and feet. ${ }^{48}$

The critic emphasizes the signs of emotion on the women's faces and his gaze is arrested by the various parts of their bodies. He even recognizes one of the models, 'a favourite actress noted for her beauty'. 49 'Olympian' artists often used famous actresses as models, whose dramatic poses reinforced the theatricality of their compositions. Alma-Tadema's composition is indeed highly theatrical: the foreground looks like a stage; the women in the background seem to come from wings situated on the left; the walls form a backdrop at the far end of the stage.

But Stephens also expressed some reservations about the subject, which to him is 'not the happiest he could have made ${ }^{50}$, probably because it evokes the threat of men's violence upon women, such as the fear of rape. Yet, Alma-Tadema complicates the drama: his maenads are both objects of men's assaults and sources of danger to the matrons. To Hedreen ${ }^{51}$, the painting implies that the matrons fear the potential danger that the maenads may represent, as they were traditionally associated with frenzy and savagery. Stephens indeed notes that the women of Amphissa are wary of the Thyades: 'the graceful group of the young dames on guard in the middle distance'. ${ }^{52}$ They were indeed renowned for their irrational practices, such as tearing up animals when intoxicated or even killing men, such as Orpheus and Pentheus, during fits of folly. However, Alma-Tadema may in fact be pointing to another idea. As some of his paintings show, he was highly interested in the potential effects of Bacchanalian contagion on orderly women; what he possibly hints at in this canvas is that the pure and ordered matrons could ritually turn into unruly beings. Although the composition is based on several horizontal planes, with each group placed in one, the maenads also form a circle around which the matrons - and so the spectators - are positioned. The maenads, who are lying, sitting or standing, create a kind of centripetal movement that seems ready to encompass the erect women of Amphissa, some of whom already bend towards the maenads. Not all the matrons wear apprehensive looks. Incidentally, the women - and not the Bacchantes - give their names to the title of the painting. The theme of the tenuous distance that separates orderly and decent women from riotous bacchantes particularly interested

${ }^{40}$ Ibid.

"Ibid.

${ }^{4 s}$ [F. G. Stephens], 'The Royal Academy (First Notice)', Athenaeum 3105 (April 30, 1887), 580-3: 581.

${ }^{49}$ Ibid.

so Ibid.

s Guy Hedreen, 'Alma-Tadema's "Women of Amphissa", The Journal of the Walters Art Gallery 52/3 (1994/1995), 79-92.

${ }^{s 2}$ Ibid. 
Alma-Tadema. His paintings often suggest that there is no clear-cut frontier between order and disruptiveness, be it in society or in the human psyche. The collapsing bacchante is not placed on the fringes but intrudes upon society precisely because what the artist shows is that any woman might abandon herself to such ritualised loss of control of the body and of the conscience. And this he represents not as threats to male spectators, but as an erotic spectacle. Alma-Tadema's biographers and the commentators of his works often quote his oral remarks on the analogies he saw between his contemporaries and ancient people. To the critic Cosmo Monkhouse, his canvases do not merely reproduce the past, but are 'pictures of scenes much nearer to us in point of time, and civilisations little different from our own' in which 'old and modern sentiment approach one another'. ${ }^{53}$ Yet such analogies were not always acceptable:

We all know that human nature is much the same in all ages, but there is a special delight in being reminded of it pictorially; and this Mr. Alma-Tadema does for us more frequently and completely than any other artist. But there is nothing more destructive of the kind of illusion that Mr. Alma Tadema desires to produce than palpable modern sentiment. ${ }^{54}$

Such sleeping women, therefore, mirror contemporary revaluations of ancient man, no longer posited as ontologically different from contemporary man. New anthropological and psychological considerations about the human psyche led to shifts in the visions of man's behaviour and psyche both in the past and in the Victorian present. Alma-Tadema tackled such questions with his peculiar aesthetic approach and pictorial language, in which eroticism plays a large part.

As is the case with Symbolism, such painting of the Antique has to be related with the nineteenth-century advances in psychology, archaeology and anthropology. These representations too draw on Greek mythology so as to explore the world of dreams, pulses and drives that lies beneath the surface - underneath the serene faces of the sleeping women and beneath the apparently smooth forms of the Antique. Ariadne and her 'Aesthetic' sisters, those sleeping beauties with Greco-Roman features, articulate various desires and fantasies and originate a complex erotic participation, while the sleeping maenad evokes animalism, trance, and the loss of control - in a context in which the border between the primitive and the modern was increasingly seen as porous.

Underneath the veil - or drapery - of the classical iconographical tradition, such images play with desire and the repressed. Despite the inscription within an academic tradition or an Aesthetic programme to legitimize the representation of the semi-nude, abandoned body of the Grecian sleeping beauty, she remains a troubling object of desire. This 'neoclassical' or 'academic painting', therefore, has to be situated in a continuity that links the Pre-Raphaelites of the preceding decades, who produced eroticized representations of Sleeping Beauties, and the later movement of European Symbolists. Alongside G. F. Watts, D. G. Rossetti and E. Burne-Jones, who often figure in books on Symbolism, painters like Leighton, Alma-Tadema, or Moore have to be appraised for their symbolist dimension. They, too, were interested in what lay beneath the surfaces, yet with a different technique. To them, Greek myths and classical forms were fit vehicles that enabled them to hint at the world of the human psyche.

"Cosmo Monkhouse, 'The Grosvenor Gallery', Academy vol. 22 (Dec. 23, 1882), 456-7: 457.

${ }^{4}$ Ibid. 


\section{Select Bibliography}

[Anon.], 'The Royal Academy', The Art journal vol. 7 (June 1, 1868), 101-10.

Barrow, J. R., Lawrence Alma-Tadema (London: Phaidon, 2001).

Carr, J. Comyns, Examples of Contemporary Art: Etchings from Representative Works by Living English and Foreign Artists (London: Chatto and Windus, 1878).

Colvin, Sidney, 'Pictures in London and Paris, 1872', Cornhill Magazine 26 (July 1872), 33 47.

Didi-Huberman, Georges, Ouvrir Vénus: Nudité, rêve, cruauté (Paris: Gallimard, 2002).

Hedreen, Guy, 'Alma-Tadema's "Women of Amphissa"', The Journal of the Walters Art Gallery 52/3 (1994/1995), 79-92.

Monkhouse, Cosmo, 'The Grosvenor Gallery', Academy vol. 22 (Dec. 23, 1882), 456-7.

Morley, Henry, 'Pictures at the Royal Academy', Fortnightly Review 11 (1872), 692-704.

Ormond, Leonée and Richard, Lord Leighton (New Haven: Yale University Press, 1975).

Phillips, Claude, 'The Royal Academy', Academy vol. 31 (May 7, 1887), 330-2.

—, Claude, 'The Royal Academy II', Academy vol. 47 (May 25, 1895), 449-50.

Phillips, Claude, 'Pictures of the year (No. I): the Royal Academy and the New Gallery', Fortnightly Review 63, ns 57 (June 1895), 925-39.

Prettejohn, Elizabeth, Art for Art's Sake: Aestheticism in Victorian Painting (New Haven \& London: Yale University Press, 2007).

Rossetti, William Michael, Notes on the Royal Academy exhibition, 1868, John Camden Hotten, 1868.

Rossetti, W. M., 'The Royal Academy Exhibition (Second Notice)', Academy vol. 7 (May 15, 1875), 513-4.

[Stephens, G. F.], 'Royal Academy', The Athenaeum 2114 (May 2, 1868), 631-33.

—, 'Note on the fine arts: Leighton's Summer Moon', Academy vol. 3 (April 15, 1872), 148.

_, 'The Royal Academy I.', Athenaeum 2323 (May 4, 1872), 563-6.

—, 'The Royal Academy (First Notice)', Athenaeum 3105 (April 30, 1887), 580-3.

—, 'The Royal Academy (First Notice)', Athenaeum 3471 (May 5, 1894), 583-9.

—, 'The Royal Academy (First Notice)', Athenaeum 3523 (May 4, 1895), 574-9.

—, 'The Royal Academy (First Notice)', Athenaeum 3679 (April 30, 1898), 571-4.

Swanson, Vern Grosvenor, The Biography and Catalogue Raisonné of the Paintings of Sir Lawrence Alma-Tadema (London: Scolar Press, 1990).

Trippi, Peter, J. W. Waterhouse (London: Phaidon, 2002).

Wedmore, Frederick, 'The Grosvenor Gallery', Academy vol. 21 (May 6, 1882), 326-7.

Wilton, Andrew, Robert Upstone, and Barbara Bryant, eds, The Age of Rossetti, Burne-Jones \& Watts: Symbolism in Britain 1860-1900 (London: Tate Gallery Publishing, 1997).

Wood, Christopher, Olympian Dreamers: Victorian Classical Painters, 1860-1914 (London: Constable, 1983). 